\title{
PROMOTING LEARNERS’ AUTONOMY THROUGH INDIVIDUALIZED LEARNING
}

\author{
Endang Fauziati \\ Universitas Muhammadiyah Surakarta \\ Jalan A. Yani Tromol Pos 1 Surakarta 57102 \\ efauziati@yahoo.com
}

\begin{abstract}
Article basically tries to explore the concept of individualized learning applicable in teaching learning process which can enhance learners' autonomy and provides a brief practical guidance on how to put this concept into classroom practices. There are at least five underlying assumptions of learning based on this concept, namely: different learning styles, a variety of sources, teacher as facilitator, integrated learning tasks, and different learning goals. It can be concluded that classroom practices designed based on these concepts can improve learners' autonomy, such as grouping, projects or tasks, and discussion.
\end{abstract}

Keywords: learners' autonomy, individualized learning

\begin{abstract}
ABSTRAK
Artikel membahas konsep pembelajaran individual yang diterapkan dalam proses pengajaran yang dapat meningkatkan otonomi pemelajar dan menyediakan pedoman singkat yang praktis untuk menerapkan konsep tersebut dalam ruang kelas. Setidaknya ada lima asumsi yang perlu digarisbawahi berdasarkan konsep tersebut, di antaranya: tipe pembelajaran yang berbeda, sumber yang bervariasi, pengajar sebagai fasilitator, tugas pembelajaran yang terintegrasi, dan tujuan pembelajaran yang berbeda. Disimpulkan, bahwa praktik di ruang kelas berdasarkan konsep tersebut dapat meningkatkan otonomi pemelajar, seperti kerja kelompok, proyek atau tugas, dan diskusi.
\end{abstract}

Kata kunci: otonomi pemelajar, pembelajaran individual 


\section{INTRODUCTION}

The goal of education is the facilitation of change and learning. An educated man is the man who has learned how to adapt and change; the man who has realized that no knowledge is secure, and that only the process of seeking knowledge gives a basis for security (Rogers, 1993). During the 1970s, the perspective on adult education has changed, basically influenced by the father of humanistic learning, that is, Carl Rogers (see Brown, 1994).

Using student-centered learning styles, adult education came to be seen as working towards goals of equality of opportunity, responsible autonomy, personal fulfillment, and democratization of education. From these ideas came the notion of autonomy, that is, "an ability to assume responsibility for one's own affairs" (Schwartz, cited in Hallgarten, 1998: 109). Such ability is not in-born but must be acquired, most often by formal learning in a systematic deliberate way.

Teaching students how to learn then is very important. This is to enable the students to make all decision about learning, such as choosing the objectives, assessing progress and performance, and selecting techniques. Katherine (1998) views such autonomy a useful goal for several reasons: Learning is more effective when the learner takes control of their own learning. He/she can study entirely on his/her own; As adults, learner and tutor are equal and power is shared. (i.e. adult learner can determine the direction of his/her own learning and a tutor is just one of the learning resources); An autonomous learner can go on learning the subject outside the classroom at the end of the course. Classroom practice is just one of the many activities that the learner can experience; And an autonomous learner can transfer learning skills to other subjects.

It is of course very important to have some discussion about motivation before starting the classroom course. Lack of explicit motivation may mean that it is difficult for the learner to reach their goals for learning. As a result, learning may not be as successful as it could be. This can be done in counseling sessions or in a group discussion.

One of the approaches which can be used to promote learner's autonomy in learning is individualized learning (Katherine, 1998: 63). This type of approach will give the opportunity for students to exercise their skills. The students will come increasingly to use the tutor as one resource amongst the many other sources such as books, magazines, the internets, their peers, etc.

This paper is basically intended to discuss ways or devices for teachers to increase learner's autonomy through individualized learning. To provide some sense of order to the presentation, this paper is divided into two major parts, namely: the concept of individualization and the classroom practices which promote learner's autonomy.

\section{DISCUSSION}

\section{The Concept of Individualization}

The effective techniques and activities, which can promote students' autonomy, would be based on the concept of individualization. Logan (1990) presents five basic assumptions regarding learning related to individualization which can be summarized as follows: People learn-even the same material—in different ways (this implies accepting different learning style); People can learn from a variety of sources, even if the final goals are the same (implying that the instructional materials can vary); Direct teaching by a teacher is not essential for learning; it is only one of many possible experiences (meaning that a teacher can be a facilitator instead of a preacher); A variety of learning 
activities can take place simultaneously (referring to integrative language-learning activities); and People may have a variety of goals or objectives for learning a second language (implying that learners learn for different reasons).

These five basic assumptions, namely: different learning styles, a variety of sources, the teacher as facilitator, integrated learning tasks, and different learning goals can lead towards individualization. These concepts of individualization can be exploited for promoting learner's autonomy. This type of learning provides learners with basic need in learning, namely: (a) exposure to the new knowledge, (b) activities for confidence building, and (c) a learner-centered approach to build rapport between the teacher and the learners (Sarwar, 1996).

Sarwar (1996) has transformed Altman's (1990) three Rs of individualization (reeducation, responsibility, and Relevance) and gives one additional $R$ (Rapport) in her teaching experiment to encourage students' active learning. The four $R s$ in her teaching prescription constitute reeducation, responsibility, relevance, and rapport. These four can be briefly discussed as follows.

First, Reeducation. This means reconstructing the role of the teacher as facilitator and the learner as the active agent in the process of learning. In Indonesian context, this change needs emphasizing, since both the teacher and the learners get used to the lecture pattern of teaching in which the student is a passive learner as the teacher 'talks' without any interaction or break for the whole teaching period.

Second, Responsibility. This implies that the learner takes charge of his own learning. For most learners, of course, this is a conceptual leap, as he gets used to rote learning and lacks confidence in his own cognitive capabilities. It also implies the teachers' responsibility to set up clearly stated tasks that can be monitored by learners on their own and ensure the availability of self-learning materials for learners.

Third, Relevance. It means finding contexts of learning that are meaningful for learners. Fourth, Rapport. Encouraging students to be more responsible for their own learning is a classmanagement challenge for any teacher. It is only through the proper rapport that an atmosphere conducive to learning can be built up. Also 'humanizing' the class is perhaps the only way to motivate learning, familiarizing one self with the learners as persons that should be treated as human beings who have thought feelings, and emotions.

The writer is of the opinion that the above principles are in accordance with the humanistic principle (i.e. Carl Rogers, 1993) which have important implications for education. To a humanist, the focus of education is learning and not teaching. The goal of education is the facilitation of learning. Learning how to learn is more important than being taught by the superior (teacher) who unilaterally decides what will be taught. Education system, then, should regard the person's freedom and dignity. What are needed then are real facilitators of learning.

Brown (2000:77) suggests that a teacher as a facilitator should have at least three characteristics, namely:

He must be genuine and real, putting away the impression of superiority or omniscience; He must have trust or acceptance from his students as valuable individuals; and He needs to communicate openly and emphatically with his students and vice versa.

A teacher with these characteristics will understand himself better. He knows to better function in the classroom as a facilitator who encourages his students to be more independent. He is far from being a spoon-feeder to his students. He will also be an effective teacher who will succeed in achieving the goal of education. We can see in Roger's humanistic view that the important aspect in learning is the context. If the context for learning is properly created, then human beings will learn everything they need to. 
In adapting Roger's (1993) ideas to teaching and learning, we need to understand that the learner is an organism who needs to understand himself and to communicate this self to others freely. The teacher as facilitators, therefore, must provide the nurturing context for learning and not to see his mission as one who should feed the students quantities of knowledge. He should foster a climate of non-defensive learning in which the learner learns not to protect him/her self from failure, from criticism, from competition with fellow students, and possibly from punishment.

In addition, the humanistic principle implies that learning should be centered on the learner. However, the learner-centeredness does not imply that the teachers should abandon the classroom to the learners. There are a number of legitimate teacher functions to the learners. Nunan (2002: 234235) presents the five most important functions of the teacher which can be summarized in the followings. First, the cognitive function. The teacher possesses knowledge desired by the students about the target language and culture. All teachers have this knowledge, which the students expect us to impart to them.

Second, the classroom management functions. Our students and the society in which we work expect us to take responsibility for how the students' time is used in the class. The students rely on our training and experience with materials, schedules, and techniques.

Third, the personal or interpersonal function. As teachers with the desired skills, knowledge and expertise, we have a great deal power in the classroom and it is our responsibility to set the tone or interpersonal classroom climate. The atmosphere we set will determine whether the students' nonlinguistic emotional needs are met in the classroom.

Fourth, the supportive function. The final function is closely related to the third, but is subtler. It has to do with the warmth and enthusiasm that the teacher radiates, that is, a vibe that he or she puts out. He believes that this is the most important function of all.

\section{Classroom Practices}

This part deals with how the concept of individualization can be employed in the classroom to promote students' autonomy. This concept is applicable to handle classroom which emphasizes either on skill or cognitive knowledge (skill course or content course). There are several things for the teacher to consider when managing the classes based on the concept of individualization; among them are presented below.

First, Grouping. On the very first day after introducing the course, the teacher can ask the students to form permanent or fixed groups consisting of four to five students. As a number of activities are to use most of the time outside the class, it would be easier for them to do their group tasks together in their free time in their friendly groups. Forming their own groups also gave learners more responsibility in sharing the class-management issues. The groups are then given a number or a name to identify their group. If it is possible they can be seated together in class with a permanent seating arrangement so they could share their group activities.

Second, Group or Individual Projects. A number of projects or tasks are also initiated. These can be assigned as group or individual tasks. To encourage participation, these tasks can be announced as one of the requirements for getting a final score for a given subject. The tasks can be in the form of a summary, a translation work, an essay, an article, or any type of written report (observation, interview). The teacher is responsible for scoring the students' tasks so that they feel that their works are rewarded. Such group project is beneficial since the teacher can reduce the workload and make the class management easier. It makes it possible for the weak students to learn from their peers. And it gives group of friends an opportunity to work together on a project in a non-threatening atmosphere. 
Third, Discussion. Discussion methods are among the most valuable tools in the teachers' repertoire. Teachers especially feel that discussion is mostly effective. The first justification is that practice makes perfect. If the teacher expects students to learn how to integrate, apply, and problem solve, it seems reasonable that students should have an opportunity to practice these skills.

Further research in cognitive psychology reveals that memory is affected by how deeply we process new knowledge. "Simply listening (lecturing system) or repeating and memorizing something (rote learning) are likely to store in such a way that we have difficulty finding it when we want to remember it” (McKeachie, 1999: 32) If we elaborate our learning by thinking about it such as explaining, summarizing, or questioning; we are more likely to remember it when we need to use it later, since they are meaningful. With such frequent exposures the information will be retained in the long term memory.

\section{CONCLUSION}

Individualized learning in classroom practices can help students to increase their autonomy in learning. With this method, teachers encourage the students to be independent and more responsible for their own learning. The underlying principles of the concept of individualization should be adopted as the basis of the approach used in promoting students to become autonomous learners.

These principles are in accordance with the humanistic principle that assumes that the focus of education is learning and not teaching. This is based on the belief that learning how to learn is more important than being taught. Learning should center on the learner. What is needed, then, is a real facilitator of learning. This is why the five most important functions of the teacher as facilitator are: the cognitive function, the classroom management function, the personal or interpersonal function, and the one who could give warmth and enthusiasm to the learners. 


\section{REFERENCES}

Altman, H.B. 1990. "Foreign Language Teaching: Focus on the Learner," In Altman, H.B. and C.V. James (Eds.) Language Teaching: Meeting Individual Needs. New York: Pergamon.

Brown, H. Douglas. 1994. Principles of Language Learning and Teaching. New York: Prentice Hall. 2000. Teaching by Principles. New York: Prentice Hall.

Hallgarten, Katherine. 1998. "Student Autonomy-Learner Training and Self-Directed Learning," in Nicholas, Sandra and Elizabeth Hoadly Maidment. Current Issues in Teaching English as a Second Language to Adults. Cambridge: C.U.P.

Harmer, Jeremy. 2000. How to Teach English: An Introduction to the Practice of English Language Teaching. Essex: Longman.

Kral, Thomas. 1996. Teacher Development: Making the Right Moves. Washington, D.C: English Language Programs Division United States Information Agency.

Logan, G.E. 1990. "Individualized Foreign Language Instruction: American Patterns for accommodating Learner differences in the classroom,” In Altman, H.B and C.V. James (Eds.) LanguageTeaching: Meeting Individual Needs. New York: Pergamon.

McKeachie, Wilbert J. et. al. 1999. Teaching Tips: Strategies, Research, and Theory for college and University Teachers. Toronto: D. C. Health and Company.

Nunan, David. 2002. Language Teaching Methodology. New York: Prentice Hall.

Sarwar, Zakia. 1999. “Adapting Individualization Techniques for Large Classes,” In Kral, Thomas (Ed.) 1996. Teacher Development: Making the Right Moves.

Washington, D.C: English Language Programs Division United States Information Agency. 